\title{
FORMING OF CORPORATE CULTURE OF FUTURE OFFICERS
}

\section{ФОРМУВАННЯ КОРПОРАТИВНОЇ КУЛЬТУРИ У МАЙБУТНІХ ОФІЦЕРІВ}

\author{
Koba Oleksandr ${ }^{1}$ \\ Kravchenko Natalia ${ }^{2}$
}

DOI: http://dx.doi.org/10.30525/978-9934-571-27-5_21

\begin{abstract}
The article deals with criteria, indicators formation of corporate culture in the future officers, and described levels of this personal phenomenon. Given the research results, opinions of the expert group and the structure of the corporate culture of the future officers and the content of its components, features professional activities of law enforcement officials to assess the level of formation of corporate culture was separated following criteria: value-personal, cognitive and activity. In this case, the formation of corporate culture for future officers concluded based on the study of their knowledge, skills and behavior in academic and extracurricular activities.

Value-personal criteria characterizing the target set for the development of future officers of the corporate culture as a value in the work of law enforcement agencies, the perception of professional values, organizational role and status and trends in the law enforcement agencies, as well as interest in the study of corporate culture and effective means of professional and interaction according to the requirements of the corporate culture and so on.

Cognitive criterion describes a set of scientific and theoretical knowledge about corporate culture in general and about the corporate culture of law enforcement in particular. It is also a student awareness of the mission of law enforcement agencies and their role in law enforcement agencies, the knowledge of the essence of corporate culture, the specifics of its manifestation in law enforcement agencies and the requirements of the corporate culture in the organization of effective personnel management, organization of interpersonal interaction to perform professional tasks.
\end{abstract}

${ }^{1}$ Candidate of Pedagogical Sciences,

Kyiv Faculty of the National Academy of the National Guard of Ukraine, Ukraine

${ }^{2}$ Kyiv Faculty of the National Academy of the National Guard of Ukraine, Ukraine 
Activity-criterion applies skills to share knowledge about the corporate culture to meet the challenges of the profession. It is a moral and normative regulation of corporate behavior, relationships and communication, respect for rules and regulations of relations prevailing in law enforcement, as well as the ability to establish interpersonal relationships, coordinate their actions with colleagues to choose the best style of communication with citizens in different situations accordance with the requirements of the corporate culture and so on.

Regarding the performance of formation of corporate culture, the following was considered a manifestation of its components. To do this using the method of expert estimates were determined minimum essential qualities, knowledge, skills and abilities of future officers, showing the formation of corporate culture.

Using these criteria can distinguish four levels of the corporate culture of the future officers: critical, say, adaptive and optimal. The criteria and indicators to assess the state of formation of the corporate culture of the future officers.

\section{1. Ветуп}

Увага до проблем формування корпоративної культури у наш час обумовлена необхідністю підвищення ефективності виконання майбутніми офіцерами своїх професійних завдань. Корпоративна культура є основою поведінки, сприйняття, пізнання, ухвалення рішень, що впливають на життєдіяльність майбутніх офіцерів та ефективність виконання завдань.

На сьогодні учені використовують різні підходи до відбору й обгрунтування критеріїв і показників корпоративної культури персоналу. Зокрема, на думку В.М. Зоріної, корпоративна культура - це багатогранний динамічний феномен, який можна вивчати на трьох рівнях поверховому (зовнішні ритуали та церемонії, психологічний клімат у колективі, стиль одягу, «міфи та легенди», «герої» та «антигерої», стиль спілкування, технології виробництва та ін.), підповерховому (цінності та вірування, стратегії і філософія, оголошена мета) та глибинному (національна культура, менталітет, особливості сприйняття) [2]. Сфера діяльності офіцера - це зона довіри між людьми, тому він повинен бути не тільки компетентним фахівцем, професіоналом, але й володіти високим рівнем корпоративної культури. ЮНЕСКО у Декла- 
рації про вищу освіту для XXI ст. наголошує, що одна 3 найважливіших функцій вищої освіти - допомагати розуміти, інтерпретувати, зберігати, розширювати, розвивати і поширювати національні й регіональні, літературні та історичні культури.

Окремі психолого-педагогічні аспекти професійної підготовки майбутніх офіцерів відображені у працях російських учених-педагогів (О. Барабанщиков, Б. Бадмаєв, В. Гурін, О. Давидов, С. Муцинов, С. Коротков та ін.). Формування професійно-етичної культури особистості розглядалось у працях зарубіжних дослідників (М. Арісаву, Р. Вільямс, Д. Джонассен, Р. Джонстон, Г. Клейман, К. Макліна, Д. Мічі, В. Оконь, С. Хантінгтон та ін.) Серед українських науковців педагогічні умови вдосконалення професійної підготовки майбутніх офіцерів у ВВНЗ досліджували М. Жиленко, Л. Мерзляк, М. Нещадим, В. Перевалов, Л. Романишина, В. Ягупов; культурологічну підготовку курсантів у ВНЗ та етику управлінської діяльності військового керівника відображено у працях В. Маслова, М. Тарнавського; деякі аспекти технології і техніки педагогічного спілкування розкрито в працях В. Кан-Калика, О. Леонтьєва, В. Пітюкова, В. Сластеніна. Але практично не досліджена проблема формування корпоративної культури як складової професійної культури офіцера.

Актуальність проблеми формування корпоративної культури майбутніх офіцерів обумовлена зовнішніми (розвиток форм і способів та швидкоплинність ведення службово-бойової діяльності; обмеження технічних можливостей у вирішенні проблем) і внутрішніми (недоліки в ідентифікації офіцерів за організаційною структурою; синдром недовіри офіцерів до організаційної структури та керівників структурних підрозділів).

За результатами проведеного анкетування майбутніх офіцерів-випускників визначено такі причини недостатнього рівня сформованості у них корпоративної культури: неповне усвідомлення майбутніми офіцерами важливості професійно-етичної культури у військовому середовищі (76,5\%); нерівномірне засвоєння ними загальнолюдських і духовних цінностей (67,8\%); відсутність цілеспрямованого формування корпоративної культури майбутніх офіцерів (89,4\%).

Актуальність проблеми дослідження підсилюється низкою суперечностей між потребою в офіцерові як педагогові нового типу і традиційною моделлю особистості майбутнього офіцера; новою педагогіч- 
ною особистісно-орієнтованою парадигмою в освіті і пріоритетністю авторитарних комунікативних форм навчання в ВНЗ; зміною традиційних ціннісних орієнтацій; стрімким скороченням кількості офіцерського складу в України.

Метою дослідження $є$ визначення особливостей та характеристика критеріїв, показників та рівнів сформованості корпоративної культури у майбутніх офіцерів.

Відповідно до мети дослідження визначено такі завдання:

1. Проаналізувати психолого-педагогічну літературу з досліджуваної проблеми, визначити сутність, структуру та особливості корпоративної культури офіцера.

2. Конкретизувати критерії та рівні сформованості корпоративної культури майбутніх офіцерів.

Для розв'язання поставлених завдань використовувався комплекс методів: теоретичні - аналіз наукових джерел з питань теоpiї культури та методики навчання і виховання; систематизація теоретичних і експериментальних даних; індукція та дедукція; порівняльний аналіз; моделювання для всебічного вивчення стану дослідження розглянутої проблеми і визначення кола дидактичних завдань для їх вирішення; емпіричні - спостереження, бесіди, анкетування, інтерв'ювання, експертне оцінювання, самооцінювання курсантів, узагальнення педагогічного досвіду й незалежних характеристик, вивчення результатів навчальної діяльності з метою визначення рівня сформованості корпоративної культури офіцерів; статистичні методи обробки - для аналізу отриманих даних і математичної обробки результатів.

Теоретико-методологічну основу дослідження становлять наступні положення: про філософію освіти (В. Андрущенко, І. Зязюн, В. Кремень, В. Лутай); про теорію наукового пізнання; особистість як активного суб'єкта життєдіяльності й розвитку; про специфіку людської діяльності (В. Асмус, С. Анісимов, А. Гусейнов, А. Лосєв); теорію й методику навчання і виховання (О. Барабанщиков, М. Нещадим, Л. Романишина, В. Ягупов та ін.); про розробку педагогічних систем (В. Беспалько, Е. Заїр-Бек, В. Серіков та ін.), педагогічних технологій (В. Биков, Т. Дмитренко, М. Кларін, В. Монахов та ін.); про спілкування і творчу діяльність особистості (В. Кан-Калік, В. Мясищев, С. Рубінштейн та ін.). 


\section{2. Формування корпоративної культури майбутнього офіцера як педагогічна проблема}

На основі історичного підходу та аналізу філософсько-етичних і педагогічних джерел нами визначено такі етапи формування корпоративної культури офіцерів: виникнення організаційної підсистеми культури в Китаї, Греції та Римській імперії, в арміях рабовласницьких і феодальних держав (близько 500 року до н.е. - до XIV-XV ст.); накопичення теоретичного і практичного матеріалу підготовки майбутніх офіцерів (юнкерів, кадетів та ін.) з моменту виникнення постійних армій і перших навчальних закладів з підготовки офіцерів (XV - кінець XIX ст.); становлення і розвиток воєнної (мілітарної) культури на основі розвитку воєнної науки (поч. XX ст. - до 90 років XX ст.); зростання ролі корпоративного управління суспільними процесами, становлення і розвиток гуманістичної парадигми освіти і особистісно-орієнтованої підготовки офіцерів у ВНЗ (з кінця 90-х років ХХ ст. і понині).

В арміях провідних країн світу чітко визначено корпоративний характер офіцерської професії. За оцінками командування Збройних сил США, для керування підлеглими як у бойовій обстановці, так і в мирний час необхідна наявність певних якостей: компетентності, відповідальності і відданості своїй справі (Ю. Кудрявцев). У ЗС Великої Британії, Німеччини підготовка офіцерських кадрів у військових навчальних закладах відзначається надзвичайною ефективністю у формуванні їх корпоративної культури. Таке порівняння є корисним i для об'єктивного оцінювання правильності обраного Україною шляху реформ у військовій освіті [1].

У літературних джерелах зустрічаються різні тлумачення терміну «корпоративна культура» (Д. Елдрідж, Х. Шварц, А. Блінов, А. Наумов). Ми під корпоративною культурою розуміємо систему професійно-етичних цінностей і якостей, що регулюють соціальні відносини в професійній взаємодії. Функції корпоративної культури (Е. Шейн; Е. Рудинська) поділяються на такі: освоєння і перетворення світу; комунікативна; сигніфікативна; накопичувальна і зберігаюча; нормативна; захисна). Джерелами формування корпоративної культури є: система особистих цінностей та індивідуально-своєрідних способів їх реалізації; способи, форми та структура організації діяльності. Залежно від характеру впливу корпоративної культури на загальну результативність діяльності виділяють позитивну і негативну корпоративну куль- 
туру. Позитивна стимулює результативність діяльності відомства і має ознаки: особистісно-орієнтована, інтегративна, стабільна. Негативна перешкоджає ефективному функціонуванню відомства і його розвитку (iї ознаки: функціонально-орієнтована; дезінтегративна; стабільна або нестабільна).

До найбільш значущих характеристик корпоративної культури належать такі: усвідомлення офіцером свого місця в соціальному інститутові, групі, підрозділі; тип спільної діяльності; прийняття норм поведінки; провідний тип управління; культура спілкування; система комунікацій; діловий етикет; традиції, звичаї, ритуали організації; особливості трактування і передачі повноважень та відповідальності; службова етика.

Загальний алгоритм формування корпоративної культури офіцера включав такі етапи: установчо-мотиваційний (формує і розвиває зовнішню і внутрішню мотивацію); змістово-пошуковий (передбачає оптимальне набуття та постійне вдосконалення професійних ЗНУ); контрольно-смисловий (спрямований на осмислення та усвідомлення курсантами цілей, змісту та специфіки майбутньої служби, на оцінювання і самооцінювання рівнів опанування корпоративної культури); адаптивно-перетворювальний (набуття досвіду реалізації службових функцій в окремих видах діяльності офіцера); системно-узагальнюючий (формування у курсантів усвідомлення сформованості рівнів корпоративної культури офіцера, визначення їх місця у загальній системі службової діяльності) та контрольно-рефлексивний (здійснення підсумкового контролю, самоконтролю, оцінювання і самооцінювання набутих знань і досвіду та організації творчої рефлексії педагогів і курсантів).

Корпоративна культура характеризується низкою компонентів (аксіологічний, технологічний, творчий, особистісний). До кожного 3 них визначені сфери й аспекти вдосконалення, розроблені конкретні педагогічні умови їх формування. Аналіз літературних джерел дозволив теоретично обгрунтувати рівні корпоративної культури майбутніх офіцерів. Майбутній офіцер з високим рівнем корпоративної культури (творчий), повинен віддано, добросовісно та патріотично виконувати обов'язок перед державою, відповідально ставитися до поставлених перед ним керівництвом завдань та уміло їх виконувати, удосконалювати свої професійні здібності та підвищувати загальнокультурний рівень. Середній рівень (усвідомлений) характеризує майбутнього 
офіцера за необхідними особистісними якостями, професійністю, пошуком творчих шляхів вирішення нових завдань, потребою у професійному зростанні, результативністю діяльності. Однак, творчість у діяльності такого офіцера зводиться до функцій «покращення, удосконалення». Офіцер з низьким рівнем (адаптаційний рівень) корпоративної культури не володіє необхідним набором професійно-особистісних характеристик, не має достатньої опори на професійні знання та уміння, не проводить творчих пошуків, не відчуває потреби в досягненні творчого та професійного рівня, отримує низькі результати та має невисокий рівень загальної культури.

Врахування конкретної особистості курсанта, його прагнення до професійного і особистісного самовдосконалення, творчої активності дозволило розширити кількість рівнів сформованості корпоративної культури і визначити відсотки курсантів, які перебувають на цих рівнях: інтуїтивний (низький;18,0\%), нормативний (адаптивний, середній; 58,6\%), усвідомлений, або активний (високий; 17,3\%) і творчий, або еталонний (вищий; 6,1\%). Отримані результати підтвердили необхідність досліджень із підвищення сформованості корпоративної культури майбутніх офіцерів.

\section{3. Вітчизняний і зарубіжний досвід формування корпоративної культури}

Результати вивчення значного масиву наукової інформації дозволяють охарактеризувати корпоративну культуру офіцера як складну інтегративну якість особистості, що визначає усвідомлення корпоративної ідеології Національної гвардії України, прийняття корпоративних інтересів та педагогічні науки відомчих стандартів поведінки в умовах повсякденної діяльності та при виконанні оперативно-службових завдань, самоідентифікацію себе як носія корпоративних цінностей.

Підгрунтям високого рівня корпоративної культури майбутніх офіцерів є усвідомлення ними значущості своєї професійної діяльності, прийняття та дотримання відомчих стандартів поведінки, корпоративної ідеології Національної гвардії України.

Аналіз досвіду багатьох успішних західних та вітчизняних відомчих структур, організацій, корпорацій, підприємств свідчить про те, що дотримання принципів корпоративної культури дозволяє значно підвищити ефективність виконання завдань, оптимізувати умови 
професійної діяльності, максимально раціонально використовувати людські та матеріальні ресурси. Сформована корпоративна культура майбутніх офіцерів $є$ важливою передумовою успішної діяльності Національної гвардії України.

Феномен корпоративної культури у західному науковому світі почали вивчати у XIX-XX століттях. Одним із перших досліджень у сфері корпоративізму та корпоративної культури здійснив М. Вебер, який визначив засади самоорганізації корпорацій, взаємозв'язок морально-етичних принципів і соціально-економічних досягнень окремих корпоративних структур. У наукових працях Ф. Тейлора, А. Файоля (концепція монополярної моделі промислової організації індустріального суспільства) ідеї М. Вебера отримали подальший розвиток [1].

Проблема формування та розвитку корпоративної культури привертала увагу й інших західних науковців. Д. Хансон досліджував історичні джерела корпоративізму, створив концепцію колективної свідомості неформальних груп. К. Камерон та Р. Куін присвятили свої наукові праці діагностиці корпоративної культури, Е. Шейн - проблемі лідерства у корпоративному середовищі, К. Девіс - генезису корпоративної культури. Д. Белл досліджував ціннісні орієнтації сучасного суспільства та їх вплив на корпоративну культуру, особливості сучасної корпоративної культури. Усі ці роботи мають велике значення для теоретичних і прикладних розробок з цієї проблематики.

Аналізу наукових концептів корпоративної та організаційної культури, їх порівняльній характеристиці присвячені дослідження науковців пострадянського простору О. Василевської, В. Співака, О. Зуєвої та інших.

Процес формування корпоративної культури в умовах громадянського суспільства висвітлювали у своїх працях М. Журовський, T. Сергеєва та інші. Особливий інтерес викликають наукові праці I. Кунде, М. Альберта, М. Мескона, Л. Карташової, Т. Ніконової та інших, що містять концептуальні підходи до виокремлення структурних елементів корпоративної культури та їх характеристики.

У зв'язку зі специфікою нашого дослідження суттєве значення мають праці, у яких розглядаються проблеми формування та розвитку корпоративної культури у національному контексті, зокрема країн пострадянського простору. У працях В. Дубяги, О. Полосіна, О. Тіунова висвітлено особливості організаційної культури російських підприємств [9]. 
Вітчизняні вчені А. Воронкова, О. Грішнова, I. Мажура, Т. Кицак вивчали роль корпоративної культури у зв'язку з проблемами формування та розвитку трудового потенціалу. У працях І. Жоган та Л. Савчук розглянуто процес формування, розвитку й особливостей корпоративної культури сучасних українських підприємств. Ю. Петрушенко та Т. Голець розкрили сутність впливу національних особливостей корпоративної культури на розвиток економічних відносин. У наукових працях П. Каткова, Г. Клейнера, С. Перегудова розглянуто процес корпоративізації соціальних структур, взаємодію політичного, економічного та корпоративного середовища.

Особливу наукову цінність для нашої дослідно-експериментальної роботи мають дослідження Т. Персикової щодо оцінки ролі первинних механізмів передачі корпоративної культури, які було покладено в основу аналізу основних чинників впливу на корпоративну культуру майбутніх офіцерів $[5 ; 11]$. Пропозиції Е. Капітонова, Г. Зінченка, О. Капітонова щодо реалізації принципу «людина - основний об'єкт уваги» було покладено в основу аналізу впливу людського чиннику на корпоративну культуру майбутніх офіцерів [3].

Результати вивчення особливостей професійної підготовки майбутніх офіцерів свідчать, що автократичне управління персоналом, менторський стиль спілкування, використання переважно командно-адміністративних інструментів впливу на персонал значно гальмують розвиток корпоративної культури майбутніх офіцерів. Вплив негативних факторів посилюється недостатньою готовністю науково-педагогічного складу створювати умови для формування корпоративного середовища та прищеплення корпоративних цінностей майбутнім офіцерам під час їх навчання у вищих навчальних закладах.

Результати дослідно-експериментальної роботи, проведеної на великому емпіричному матеріалі, дали змогу виявити такі проблеми: недостатній ступінь усвідомлення випускниками ВНЗ ролі корпоративної ідеології для успішного функціонування Національної гвардії України. Так, наприклад, результати аналізу відгуків на випускників свідчать, що їм бракує усвідомлення цінності служби як умови розкриття особистісного потенціалу $(17,3$ \%), самоідентифікації себе як носія корпоративних цінностей $(13,4$ \%), усвідомлення значення спільних цінностей (14,5 \%). Значна кількість респондентів (45,2 \%) у відповідях опосередковано вказала на наявність негативної корпора- 
тивної культури: низьку адаптацію до корпоративних вимог (11,2%); неможливість творчої самореалізації й саморозвитку, самовдосконалення (23,7 \%); недостатню партнерську взаємодію (10,3 \%).

Проведене дослідження підтвердило виняткову важливість конкретних емоційних, соціальних, економічних, культурних, етичних, професійних аспектів діяльності кожного учасника у процесі формування корпоративної культури. Проблема формування корпоративної культури майбутніх офіцерів найбільше пов'язана з людським чинником, людський ресурс є невичерпним джерелом трансформацій корпоративної культури. Значний вплив на якісні параметри корпоративної культури мають сімейне життя, труднощі у стосунках, відчуття матеріальної невлаштованості. Так, наприклад, 55,8 \% респондентів у відповідях вказали на високий ступінь впливу зазначених чинників на корпоративне середовище та його якість.

Особливу роль у формуванні корпоративної культури майбутніх офіцерів відіграють механізми первинної передачі корпоративної культури. Результати аналізу проведеного опитування дали змогу виявити труднощі у реалізації зазначених механізмів: 14,7 \% респондентів вважають, що недостатньо якісно здійснюється вибір об'єктів уваги, оцінки та контролю; 11,4 \% респондентів вважають необхідними корективи у механізмі розподілу заохочень; 10,2 \% респондентів вважають недостатньою роботу у напрямку створення зразків управлінської та виконавської поведінки для наслідування.

Результати аналізу зазначених чинників дають підстави виділити низку суперечностей при формуванні корпоративної культури майбутніх офіцерів: між необхідністю підготовки майбутніх офіцерів 3 урахуванням загальноєвропейських стандартів і недостатньою розробленістю теоретико-методичних основ формування корпоративної культури; вимогами відомчих стандартів культури служби щодо рівня корпоративної культури майбутніх офіцерів та несформованістю у курсантів рефлексивного ставлення до їх змісту; необхідністю формування духу корпоративізму у майбутніх офіцерів та індивідуалізмом, кар'єрними перегонами, впливом негативних факторів на курсантські колективи; необхідністю підвищення престижності служби та нерозробленістю дієвого корпоративного інструментарію для досягнення цієї мети в умовах вищого навчального закладу; наявністю у курсантів бажання оволодіти основами корпоративної культури офіцера та 
відсутністю відповідної навчальної дисципліни у вищих навчальних закладах.

На основі аналізу суперечностей доцільно сформувати пропозиції щодо їх подолання: по-перше, актуальною та своєчасною буде популяризація проблеми формування корпоративної культури майбутніх офіцерів, проведення відповідних тренінгів, семінарів; по-друге, створення та реалізація матеріалів курсу «Корпоративна культура офіцера»; по-третє, постійний моніторинг якості механізмів первинної передачі корпоративної культури та внесення необхідних корективів; по-четверте, використання можливостей щодо формування корпоративної культури майбутніх офіцерів шляхом спеціально організованого навчання.

Отже, інструментарій формування корпоративної культури майбутніх офіцерів потребує значних корективів. Основну роль у цьому процесі можуть відігравати механізми первинної передачі корпоративної культури, що буде сприяти формуванню сильної корпоративної культури офіцерів. Важливим є те, що корпоративна культура офіцерів фіксує цінність професійної діяльності як одного із шляхів особистісної самореалізації й саморозвитку, цінність служби як умови забезпечення власних актуальних потреб. Майбутні офіцери мають усвідомлювати вплив корпоративної культури на власну кар'єру. Високий рівень корпоративної культури буде сприяти усвідомленню спільних інтересів, повазі та самоповазі, командній взаємодії, вірі в керівництво, вірі у справедливість, діловій активності персоналу.

\section{4. Критерії та рівні сформованості корпоративної культури майбутніх офіцерів}

Окрім теоретичного аналізу науково-педагогічної літератури, для визначення критеріїв сформованості корпоративної культури майбутніх офіцерів було проведено додаткові бесіди з офіцерами та керівниками курсантських груп. 3 урахуванням результатів наукових досліджень, думок експертної групи та структури корпоративної культури майбутніх офіцерів і змісту ії компонентів, особливостей професійної діяльності фахівців для оцінки рівня сформованості їх корпоративної культури було виокремлено такі критерії: ціннісно-особистісний, когнітивний та діяльнісний. У цьому випадку про сформованість корпоративної культури майбутніх офіцерів органів було зроблено висновок 
на основі вивчення їхніх знань, умінь і навичок, а також поведінки в навчальній та позанавчальній діяльності [4].

Насамперед взято до уваги, що иіннісно-особистісний критерій характеризує цільову установку майбутнього офіцера на розвиток корпоративної культури як цінності в діяльності Національної гвардії України, сприйняття ним цінностей професійного, організаційного та статусно-рольового характеру, а також інтерес до корпоративної культури та вивчення ефективних засобів організації професійної діяльності та взаємодії відповідно до вимог корпоративної культури та ін.

Когнітивний критерій характеризує сукупність науково-теоретичних знань про корпоративну культуру. Знання сутності корпоративної культури, специфіки іiї вияву і вимог корпоративної культури при організації ефективного управління персоналом, організації міжособистісної взаємодії для виконання професійних завдань.

Діяльнісний критерій стосується умінь використовувати здобуті знання про корпоративну культуру для вирішення завдань професійної діяльності. Йдеться про моральну й корпоративну нормативність регуляції поведінки, відносин і комунікацій; дотримання норм і правил взаємин, а також уміння встановлювати міжособистісні зв'язки, узгоджувати свої дії з діями колег, вибирати оптимальний стиль спілкування 3 громадянами в різних ситуаціях відповідно до вимог корпоративної культури та ін $[6 ; 8]$.

Щодо показників сформованості корпоративної культури, то такими було визнано вияв їі компонентів. Для цього за допомогою методу експертних оцінок було визначено мінімум найважливіших якостей, знань, умінь і здібностей майбутніх офіцерів, що свідчать про сформованість корпоративної культури [10].

Загалом визначено, що ціннісно-особистісному критерію професійно-психологічної компетентності майбутніх офіцерів відповідають такі показники:

- прийняття цільової установки на розвиток корпоративної культури як цінності в діяльності Національної гвардії України;

- сприйняття цінностей професійного, організаційного та статусно-рольового характеру;

- інтерес до корпоративної культури та вивчення ефективних засобів організації професійної діяльності та взаємодії; намагання підвищити свій рівень знань про корпоративну культуру; 
- сформованість професійно необхідних якостей, насамперед патріотизму, відданості професійному обов'язку, підпорядкованості закону, дисциплінованості, комунікабельності тощо.

У свою чергу когнітивному критерію корпоративної культури майбутніх офіцерів відповідають такі показники:

- усвідомлення місії Національної гвардії України та своєї ролі в службово-бойовій діяльності ;

- знання сутності корпоративної культури та специфіки її вияву в службово-бойовій діяльності;

- розуміння значимості знань про корпоративну культуру для майбутньої службової діяльності та значимості корпоративної культури для ефективного виконання професійних завдань;

- знання вимог корпоративної культури при організації ефективного управління персоналом, організації міжособистісної взаємодії при виконанні професійних завдань.

Діяльнісному критерію корпоративної культури майбутніх офіцерів відповідають такі показники:

- моральна й корпоративна нормативність регуляції поведінки, відносин і комунікацій, дотримання норм і правил взаємин;

- уміння встановлювати міжособистісні зв'язки, узгоджувати свої дії $з$ діями колег, вибирати оптимальний стиль спілкування з громадянами в різних ситуаціях відповідно до вимог корпоративної культури;

- організованість, професійна відповідальність, відданість традиціям, підтримка привабливого іміджу офіцера;

- адекватна самооцінка, уміння здійснювати емоційно-вольову регуляцію поведінки та самоконтроль відповідно до вимог корпоративної культури Національної гвардії України.

Використання зазначених критеріїв і показників дозволило визначити рівні сформованості корпоративної культури у майбутніх офіцерів. При цьому було враховано загальноприйняті у педагогіці підходи щодо дослідження рівнів сформованості відповідного педагогічного феномену. Аналіз наукової літератури дозволив з'ясувати, що дослідники виокремлюють декілька рівнів сформованості корпоративної культури. Зокрема Л. Валіахметова веде мову про три рівні сформованості корпоративної культури співробітників кредитно-фінансових організацій: високий, середній та низький. Т. Романюк для визначення сформованості корпоративної культури майбутніх фахівців 
сфери сервісу також пропонує використовувати трирівневу шкалу. Такої ж позиції дотримується і О. Разумова. У свою чергу О. Чижикова для визначення рівнів сформованості корпоративної культури серед студентів використовувала чотирибальну шкалу: незадовільний, низький, достатній та оптимальний. А. Метельков для характеристики сформованості корпоративної культури майбутніх офіцерів-прикордонників також пропонує чотирирівневу шкалу, зокрема учений веде мову про такі рівні, як оптимальний, адаптаційний, допустимий та критичний [2].

Отже, залежно від підстав для виявлення рівнів сформованості корпоративної культури дослідники використовують три- або чотирирівневу шкалу. На нашу думку, виділення тільки трьох рівнів не дозволяє чітко з'ясувати динаміку корпоративної культури. Узагальнення отриманих теоретичних й емпіричних результатів, зокрема урахування праць О. Чижикової та А. Метелькова, дозволило розробити системні описи корпоративної культури майбутніх офіцерів на основі чотирирівневої шкали. Далі якісно охарактеризуємо курсантів, що мають відповідний рівень сформованості корпоративної культури.

Курсанти 3 критичним рівнем сформованості корпоративної культури не завжди сприймають цільову установку на розвиток корпоративної культури як цінності в діяльності Національної гвардії України. Вони в багатьох випадках не сприймають цінностей професійного, організаційного та статусно-рольового характеру; інтерес до корпоративної культури й вивчення ефективних засобів організації професійної діяльності та взаємодії у них епізодичний. Курсанти недостатньо намагаються підвищити свій рівень знань про корпоративну культуру, хоча вони розуміють необхідність сформованості професійно необхідних якостей, насамперед патріотизму, відданості професійному обов'язку, підпорядкованості закону, дисциплінованості, комунікабельності тощо, але не завжди дотримуються таких вимог.

Такі курсанти нечітко усвідомлюють місію Національної гвардії України та свою роль в службово-бойової діяльності, дуже слабо обізнані із сутністю корпоративної культури та специфікою іiі вияву в Національної гвардії України, недостатньо розуміють значимість знань про корпоративну культуру для майбутньої службової діяльності та її значимості для ефективного виконання професійних завдань. 
Вони слабо обізнані з вимогами корпоративної культури під час організації управління персоналом, організації міжособистісної взаємодії для виконання професійних завдань.

Такі курсанти мають низький рівень моральної й корпоративної нормативності регуляції поведінки, відносин і комунікацій, нечітко дотримуються норм і правил взаємин, що склалися в підрозділах, майже не вміють установлювати міжособистісні зв'язки, узгоджувати свої дії з діями колег, вибирати оптимальний стиль спілкування з громадянами в різних ситуаціях відповідно до вимог корпоративної культури. Вони недостатньо організовані та відповідальні, не завжди віддані традиціям Національної гвардії України, слабо підтримують імідж офіцера. Самооцінка у таких курсантів не завжди адекватна, вони недостатнім чином уміють здійснювати емоційно-вольову регуляцію поведінки та самоконтроль відповідно до вимог корпоративної культури Національної гвардії України.

Курсанти 3 допустимим рівнем сформованості корпоративної культури переважно правильно сприймають цільову установку на розвиток корпоративної культури як цінності в діяльності Національної гвардії України. Вони здебільшого сприймають цінності професійного, організаційного та статусно-рольового характеру в службово-бойовії діяльності; цікавляться питаннями корпоративної культури й ефективними засобами організації професійної діяльності та взаємодії. Курсанти досить часто амагаються підвищити свій рівень знань про корпоративну культуру, вони розуміють необхідність сформованості професійно необхідних якостей, насамперед патріотизму, відданості професійному обов'язку, підпорядкованості закону, дисциплінованості, комунікабельності тощо й намагаються дотримуватися таких вимог.

Такі курсанти переважно правильно усвідомлюють місію Національної гвардії України та свою роль в службово-бойовій діяльності, дещо обізнані із сутністю корпоративної культури та специфікою іiі вияву в служби, здебільшого розуміють значимість знань про корпоративну культуру для майбутньої службової діяльності та їі значимість для ефективного виконання Національної гвардії України професійних завдань. Вони обізнані з вимогами корпоративної культури під час організації управління персоналом, організації міжособистісної взаємодії для виконання професійних завдань. 
Для таких курсантів характерний належний рівень моральної та корпоративної нормативності регуляції поведінки, відносин і комунікацій, вони намагаються дотримуватися норм і правил взаємин, що склалися, установлювати міжособистісні зв'язки, узгоджувати свої дії 3 діями колег, вибирати оптимальний стиль спілкування з громадянами в різних ситуаціях відповідно до вимог корпоративної культури. Вони здебільшого організовані та відповідальні, виявляють відданість традиціям Національної гвардії України, намагаються підтримувати імідж офіцера. Самооцінка в таких курсантів у багатьох випадках адекватна, вони намагаються здійснювати емоційно-вольову регуляцію поведінки та самоконтроль відповідно до вимог корпоративної культури Національної гвардії України.

Курсанти 3 адаптаційним рівнем сформованості корпоративної культури правильно сприймають цільову установку на розвиток корпоративної культури як цінності в діяльності Національної гвардії України. Вони досить виважено сприймають цінності професійного, організаційного та статусно-рольового характеру, часто цікавляться питаннями корпоративної культури й ефективними засобами організації професійної діяльності та взаємодії. Курсанти майже завжди намагаються підвищити свій рівень знань про корпоративну культуру, вони розуміють необхідність сформованості професійно необхідних якостей, насамперед патріотизму, відданості професійному обов'язку, підпорядкованості закону, дисциплінованості, комунікабельності тощо й дотримуються таких вимог.

Такі курсанти правильно усвідомлюють місію Національної гвардії України та свою роль, обізнані із сутністю корпоративної культури та специфікою їі вияву, розуміють значимість знань про корпоративну культуру для майбутньої службової діяльності та її значимість для ефективного виконання Національної гвардії України професійних завдань. Вони належно обізнані з вимогами корпоративної культури під час організації управління персоналом, організації міжособистісної взаємодії для виконання професійних завдань.

Для таких курсантів характерний відповідний рівень моральної й корпоративної нормативності регуляції поведінки, відносин і комунікацій, вони здебільшого дотримуються норм і правил взаємин, що склалися в підрозділах, уміють установлювати міжособистісні зв'язки, узгоджувати свої дії з діями колег, вибирати оптимальний стиль спіл- 
кування з громадянами в різних ситуаціях відповідно до вимог корпоративної культури. Вони досить організовані та відповідальні, віддані традиціям Національної гвардії України, майже завжди намагаються підтримувати імідж офіцера. Самооцінка у таких курсантів досить адекватна, вони уміють здійснювати емоційно-вольову регуляцію поведінки та самоконтроль відповідно до вимог корпоративної культури Національної гвардії України.

Курсанти з оптимальним рівнем сформованості корпоративної культури завжди правильно сприймають цільову установку на розвиток корпоративної культури як цінності в діяльності Національної гвардії України. Вони сприймають усі цінності професійного, організаційного та статусно-рольового характеру, грунтовно цікавляться питаннями корпоративної культури й ефективними засобами організації професійної діяльності та взаємодії. Курсанти весь час намагаються підвищити свій рівень знань про корпоративну культуру, у них сформовані такі професійно необхідні якості, як патріотизм, відданість професійному обов'язку, підпорядкованість закону, дисциплінованість, комунікабельність тощо. Такі курсанти усвідомлюють місію Національної гвардії України та свою роль, вони грунтовно обізнані із сутністю корпоративної культури та специфікою її вияву, завжди розуміють значимість знань про корпоративну культуру для майбутньої службової діяльності та іiі значимість для ефективного виконання Національної гвардії України професійних завдань. Вони грунтовно обізнані з вимогами корпоративної культури під час організації управління персоналом, організації міжособистісної взаємодії для виконання професійних завдань.

Для таких курсантів характерний високий рівень моральної й корпоративної нормативності регуляції поведінки, відносин і комунікацій, вони завжди дотримуються норм і правил взаємин, що склалися в підрозділах, належним чином уміють установлювати міжособистісні зв'язки, узгоджувати свої дії з діями колег, вибирати оптимальний стиль спілкування з громадянами в різних ситуаціях відповідно до вимог корпоративної культури. Вони завжди організовані та відповідальні, віддані традиціям Національної гвардії України, підтримують імідж офіцера. Самооцінка у таких курсантів адекватна, вони належним чином уміють здійснювати емоційно-вольову регуляцію поведінки та самоконтроль відповідно до вимог корпоративної культури Національної гвардії України. 


\section{5. Висновки}

Отже, узагальнення результатів аналізу психолого-педагогічної літератури дозволяє стверджувати, що сформованість корпоративної культури майбутніх офіцерів можна оцінити за трьома критеріями, які характеризують іiі структурні компоненти, зокрема ціннісно-особистісним, когнітивним та діяльнісним. Використання зазначених критеріїв дозволяє виділити чотири рівні сформованості корпоративної культури майбутніх офіцерів: критичний, допустимий, адаптаційний та оптимальний. Визначені критерії і показники дозволяють оцінити стан сформованості корпоративної культури майбутніх офіцерів.

Перспективами подальших досліджень $\epsilon$ обгрунтування оновлення змісту програм навчальних дисциплін гуманітарного блоку через упровадження інноваційних культурно-освітніх та інформаційних технологій у підготовці офіцерських кадрів нової генерації.

\section{Список літератури:}

1. Дмитренко М.Й. Корпоративна культура у констеляціях пізнього модерну: філософсько-антропологічні експлорації: автореф. дис. на здоб. наук. ступ. докт. філос. наук: 09.00.04 / М.Й. Дмитренко. - Х., 2014. - 31 с.

2. Зоріна, В.М. Корпоративна культура та її складові / В.М. Зоріна // Педагогіка і психологія формування творчої особистості: проблеми і пошуки: зб. наук. пр. / Ін-т педагогіки і психології проф. освіти АПН України, Запоріз. облас. ін-т післядиплом. пед. освіти. - К.; Запоріжжя, 2005. Вип. 34. - С. 91-95.

3. Кузьмин Е.С. Вопросы социальной психологии руководства / Е.С. Кузьмин. -- Л., 1977. - С. 185.

4. Ломов Б.Ф. Методические и теоретические проблемы психологии / Б.Ф. Ломов. - М.: Наука. - 1984. -348 с.

5. Мисюк С. Б. Формування стилю корпоративної культури загальноосвітнього навчального закладу [Електронний ресурс] / С. Б Мисюк. - Режим доступу: http://journal.osnova.com.ua/download/29-123-40646.pdf

6. Орбан-Лембрик, Л.Е. Психологія управління: навч. посіб. / Л.Е. ОрбанЛембрик. - 2-е вид., допов. - К.: Академвидав, 2010. - 543 с.

7. Тернопільська В.І. Довідник з виховної роботи зі студентами: навч. посібник / В.І. Тернопільська. - Тернопіль: Вид-во «Богдан», 2014. - 184 с.

8. Чернишова Т.О., Немченко Т.А. Деякі аспекти корпоративної культури організації / Т.О. Чернишова, Т.А. Немченко // Наукові праці КНТУ. Економічні науки. - 2010. - Вип. 17. - С. 25-31.

9. Шаполова В. В. Роль корпоративної культури у підвищенні якості підготовки студентів-менеджерів вищого технічного навчального закладу / В. В. Шаполова // Теорія і практика управління соціальними системами. - 2011. - № 4. - С. 101-106. 
10. Kovalevskyy S.V. Research the Corporate Culture of Students Using Neural Network Models / S.V. Kovalevskyy, L.V. Kosheva // American Journal of Neural Networks and Applications. - 2015. - Vol. 1, No. 2. - P. 43-47. - doi: 10.11648/j. ajnna.20150102.13.

11. Ternopilska V. The role of self-government in development of leadership qualities among students / V. Ternopilska // Problems of development modern science: theory and practice: Collection of scientific articles. - EDEX, Madrid, Espana, 2016. - P. 341-344.

\section{References:}

1. Dmytrenko M.J. (2014). Korporatyvna kuljtura u konsteljacijakh piznjogho modernu: filosofsjko - antropologhichni eksploraciji [Corporate culture in constellations of late modern: philosophical - anthropological exploitation]: extended abstract of candidate's: 09.00.04. Kh., 31 (ukr).

2. Zorina V.M. (2005). Korporatyvna kuljtura ta jiji skladovi [Corporate culture and its components]. Pedaghoghika i psykhologhija formuvannja tvorchoji osobystosti: problemy i poshuky: zb. nauk. pr. Vyp. 34, 91-95 (ukr).

3. Kuz'min E.S. (1977). Voprosy social'noj psihologii rukovodstva [Issues of social management psychology]. L.,185 (rus).

4. Lomov B.F. (1984). Metodicheskie i teoreticheskie problemy psihologii [Methodical and theoretical problems of psychology]. M.: Nauka, 348 (rus).

5. Mysyuk S. B. Formuvannya stylyu korporatyvnoyi kul'tury zahal'noosvitn'oho navchal'noho zakladu [The style forming corporate culture of an educational institution]. Available at: http://journal.osnova.com.ua/download/29-123-40646.pdf (ukr).

6. Orban-Lembryk L.E. (2010). Psykhologhija upravlinnja [Psychology of management]: navch. posib. K.: Akademvydav, 543 (ukr).

7. Ternopiljsjka V.I. (2014). Dovidnyk z vykhovnoji roboty zi studentamy [Handbook of educational work with students]: navch. Posibnyk. Ternopilj: Vyd-vo "Boghdan", 184 (ukr).

8. Chernyshova T.O., Nemchenko T.A. (2010). Dejaki aspekty korporatyvnoji kuljtury orghanizaciji [Some aspects of the corporate culture of the organization]. Naukovi praci KNTU. Ekonomichni nauky. Vyp. 17, 25-31 (ukr).

9. Shapolova V. V. (2011). Rol' korporatyvnoyi kul'tury u pidvyshchenni yakosti pidhotovky studentivmenedzheriv vyshchoho tekhnichnoho navchal'noho zakladu [The role of corporate culture in improving the quality of students-managers of higher technical educational institution]. Teoriya i praktyka upravlinnya sotsial'nymy systemamy, 4, 101-106 (ukr).

10. Kovalevskyy S.V. (2015). Research the Corporate Culture of Students Using Neural Network Models. American Journal of Neural Networks and Applications. Vol. 1, No. 2, 43-47. doi: 10.11648/j.ajnna.20150102.13 (eng).

11. Ternopilska V. The role of self-government in development of leadership qualities among students / V. Ternopilska // Problems of development modern science: theory and practice: Collection of scientific articles. - EDEX, Madrid, Espana, 2016. - p. 341-344 (eng). 